\title{
Effect of Tillage and Nutrient Management on Economics and Soil Status by Maize + Pigeon Pea Intercropping System
}

\section{Pradeep Kumar ${ }^{1 *}$, Mritunjay Kumar ${ }^{2}$, Santosh Kumar Singh ${ }^{1}$, Gharsiram $^{1}$ and Satish Bhutekar ${ }^{1}$}

${ }^{1}$ Agronomy Student of Dr. Rajendra Prasad Central Agricultural University, Pusa, Bihar, India

${ }^{2}$ Director of Centre for Start-up Facilitation, Dr. Rajendra Prasad Central Agricultural University, Pusa, Bihar, India

*Corresponding Author: Pradeep Kumar, Agronomy Student of Dr. Rajendra Prasad Central Agricultural University, Pusa, Bihar, India.
Received: October 12, 2020

Published: November 21, 2020

(C) All rights are reserved by Pradeep Kumar., et al.

\section{Abstract}

A field experiment was carried out during the summer (kharif) seasons of 2019-20 at research farm field in TCA, Dholi, under Dr. RPCAU, Pusa, Samastipur (Bihar). The experiment was laid out in split plot design with 4 main plot treatment viz., T 1: Permanent bed (PB), T 2: Zero tillage (ZT), T 3: Fresh bed (FB) and T 4: Conventional tillage and 3 sub-plot treatment viz., N 1: 100\% Recommended dose of fertilizer (RDF), N 2: 120\% Recommended dose of fertilizer (RDF) and N 3: 80\% Recommended dose of fertilizer (RDF) witch were replicated thrice. Considering the overall impact of conservation agriculture practices, growing maize+pigeon pea intercropping under PB, crop recorded higher maize equivalent yield (130.7 q/ha) at par with ZT (120.7 q/ha) over the FB (112.1 q/ ha) and CT (108.4 q/ha) while, 120\% RDF application recorded (127.7 q/ha) over the 100\% RDF (117.7 q/ha) and 80\% RDF (108.6 $\mathrm{q} / \mathrm{ha}$ ) application under nutrient management. The gross return, net return and B:C ratio from maize+pigeon pea intercropping obtained significantly higher under PB (244839, 189239 and 3.4) compared to FB (210514, 153665 and 2.7) and CT (203320, 147070 and 2.6) while under nutrient management, the gross return, net return and B:C ratio recorded higher with $120 \%$ RDF application (239028, 181223 and 3.1) compared to 80\% RDF (204076, 150031 and 2.8). the soil physico-chemical properties viz., bulk density, pH, EC, organic carbon, available N, P and K were also favourably influenced by PB and ZT practices but it's were not significantly affected by nutrient management practices. Appropriate tillage practices and nutrient management are some of the reasons behind the increasing economics or net returns of crop. Therefore, the study was conducted to identify the appropriate tillage practices and suitable nutrient management in new immersing maize + pigeonpea intercropping system in an alternative conventional farming. Keywords: Tillage; Nutrient Management; Economics; Soil Status; Maize + Pigeon Pea

\section{Introduction}

Agricultural systems are already affected by several challenges while climate variability and climate change are accentuating further these negative impacts on food production McKersie, 2015 [14]. In changing climate, we adopt the crops, variety and production technology that suitable in this climate, like altering in planting pattern and intercropping practices. In India after green revolution continuous cereal-cereal based production systems coupled with conventional cultivation practices has led to numerous production vulnerabilities Paul., et al. 2014 [21]. Thus, in order to sustain the soil and crop productivity, the minimum soil disturbance, organic soil cover and crop diversification assume great importance Gangwar., et al. 2006 [4]. Crop diversification through intervention of legumes as well as integrated crop, soil, nutrient and pest management are some of the viable options to cope up the emerging challenges in Indian agriculture. In this study we conduct a field experi- 
ment on maize + pigeonpea (2:2) intercropping on different tillage and nutrient management practices. Maize crop has highest yield potential among the all cereals crop that increase the net benefit of farmer. Although, our honourable prime minister also says the doubling the farmer income up to 2022. So, the main aim of this experiment to doubling the small farmer income through maize + pigeon pea intercropping system. Because under Bihar condition the traditional pigeon pea grown as long duration crop that gain the lower net income. As well as cereal + legume intercropping sustains the soil health and other physicochemical property of soil. Maize and pigeon pea production can be improved by using better inputs, proper production technology and by proper tillage practices that reduce the cost of cultivations. Tillage contributes in yield up to $20 \%$ among all the crop production factors Ahmad., et al. 1996 [16]. Use of intensive and unnecessary conventional tillage practices is often harmful to soil and also increase the cost of cultivation. Therefore, currently there is a significant interest and emphasis on the shift to the permanent bed and zero-tillage for increasing the net economic benefit to farmer and without affect the natural resources maintain the soil health and controlling erosion process and increasing crop production Dawelbeit and Babiker, 1997 [12].

Appropriate tillage practices and nutrient management are some of the reasons behind the increasing economics or net returns of crop and also conservation tillage with nutrient management practices impact on enhancing soil fertility status. Therefore, the study was conducted to identify the appropriate tillage practices and suitable nutrient management in new immersing maize + pigeonpea intercropping system in an alternative conventional farming.

\section{Material and Methods}

A field experiment was carried out during the summer (kharif) seasons of 2019-20 at research farm field in TCA, Dholi, under Dr. RPCAU, Pusa, Samastipur (Bihar). The experiment was executed in split plot design with three replications having net plot size of $8.44 \mathrm{~m} \times 4.20 \mathrm{~m}$.

The experiment consists of following treatments.

\section{A: Tillage practices (Main plot)}

$\mathrm{T} 1=$ Zero tillage

$\mathrm{T} 2=$ Permanent bed
T3 = Fresh bed

$\mathrm{T} 4$ = Conventional tillage.

\section{B: Nutrient management (Sub plots)}

$\mathrm{N} 1=100 \% \mathrm{RDF}$

$\mathrm{N} 2=120 \% \mathrm{RDF}$

$\mathrm{N} 3=80 \%$ RDF

Pigeon pea variety 'Bahar' and Maize 'P3322' were sown in $3^{\text {rd }}$ week of June and maize was harvested in third week of October while the pigeon pea was harvested in second week of April next year of experimentation. Maize and pigeon pea were sown in 2:2 ratio row $67 / 20 \mathrm{~cm}$ apart and plant to plant distance of $20 \mathrm{~cm}$ were maintained by thinning at 15 days after sowing. The recommended dose of fertilizers i.e. Maize (120:60:50 NPK Kg/ha) and pigeon pea (30:50:30 NPK Kg/ha) were given individually. Full dose nitrogen, phosphorous and potassium in pigeon pea were applied at the time of sowing according to the treatment in each plot. However, in maize, half of nitrogen, full dose of phosphorous and potassium were applied at the time of sowing and remaining nitrogen was top dressed in two equal splits i.e. $1 / 4^{\text {th }}$ at knee-high and $1 / 4^{\text {th }}$ at tasseling stage of the crop according to the treatment in each plot. One hand weeding was done at 30 day of sowing. The initial and final pH, EC, bulk density, organic carbon, N, P and K content of soil were analysed as per standard methods. For comparison between treatments, the yields of crops were converted into maize equivalent yield on prevailing market price Tomar and Tiwari, 1990 [34].

\section{Results}

Maize equivalent yield

Maize equivalent yield significantly affected by both tillage and nutrient management treatments (Table 1). Under the tillage practices, permanent bed gave the highest maize equivalent yield over to fresh bed and conventional tillage treatment. PB recorded significantly higher MEY (130.7 q ha-1) which was at par with the ZT (120.7 q ha ${ }^{-1}$ ) followed by FB (112.09 q ha-1) and CT (108.37 q $\mathrm{ha}^{-1}$ ), respectively. As like, tillage practices, nutrient management was also significantly differed the MEY. $120 \%$ RDF treatment recorded significantly high MEY (127.6 q ha-1), which was over the 100\% RDF (117.70 q ha-1) and 80\% RDF (108.56 q ha-1) nutrient management. 


\begin{tabular}{|l|c|}
\hline Treatments & MEQ (q/ha) \\
\hline Tillage practices & 120.7 \\
\hline Zero Tillage & 130.7 \\
\hline Permanent Bed & 112.1 \\
\hline Fresh Bed & 108.4 \\
\hline Conventional tillage & 2.95 \\
\hline SEm \pm & 10.2 \\
\hline LSD (p =0.05) & \\
\hline Nutrient management & 117.7 \\
\hline $100 \%$ RDF & 127.7 \\
\hline $120 \%$ RDF & 108.6 \\
\hline $80 \% R D F$ & 2.39 \\
\hline SEm \pm & 7.2 \\
\hline LSD (p = 0.05) & NS \\
\hline LSD (p = 0.05) (T×N Interaction) & \\
\hline
\end{tabular}

Table 1: Maize equivalent yield ( $\mathrm{q} / \mathrm{ha}$ ) of maize affected by tillage and nutrient management practices.

\section{Gross returns, net returns and B: C ratio}

The economic data like Gross returns, net returns and B: C ratio was significant differed by tillage practices (Table 2). Among the tillage practices, the gross returns were significantly superior in PB (244839 ₹/ha) which was statistically over to ZT (226434 ₹/ha),
FB (210514 ₹/ha) and CT (203320 ₹/ha). As well as net returns also significantly higher found in PB (189239 ₹/ha) which was at par with ZT (171434 ₹/ha) and over with FB (153665 ₹/ha) and CT (147070 ₹/ha). Whereas significantly superior B: C ratio was found in PB (3.4) which was statistically at par with ZT (3.1) over FB (2.7) and CT (2.6). Across nutrient management treatments significantly highest gross returns was obtained in 120\% RDF (239028 ₹/ha) which was statistically over 100\% RDF (220727 ₹/ha) and 80\% RDF (204076 ₹/ha). Similarly, higher net returns were found in $120 \%$ RDF (181223 ₹/ha) which was statistically over $100 \%$ RDF (164802 ₹/ha) and 80\% RDF (150031 ₹/ha). The benefit: cost ratio was highest in $120 \%$ RDF (3.13) which was at par with $100 \%$ RDF (2.9) over the $80 \%$ RDF (2.7). Similarly, the cost of cultivation of maize pigeon pea intercropping system varied in tillage and nutrient management practices. Maximum cost of cultivation was found in FB, $120 \%$ RDF (58730 ₹/ha) treatment. Whereas, minimum cost of cultivation was found in ZT, 80\% RDF (53120₹/ha) treatment.

\section{Soil physico-chemical property}

The soil physical properties viz., bulk density was significantly influenced by tillage practices (Table 3). Under tillage practice, bulk density the minimum values were obtained in PB and ZT (1.27 and $1.28 \mathrm{~g} \mathrm{~cm}^{-3}$ ) and maximum was recorded in CT and FB (1.35 and $\left.1.32 \mathrm{~g} \mathrm{~cm}^{-3}\right)$.

\begin{tabular}{|c|c|c|c|}
\hline Treatments & Gross returns (₹/ha) & Net returns (₹/ha) & Benefit: cost ratio \\
\hline \multicolumn{4}{|l|}{ Tillage practices } \\
\hline Zero Tillage & 226434 & 171434 & 3.1 \\
\hline Permanent Bed & 244839 & 189239 & 3.4 \\
\hline Fresh Bed & 210514 & 153665 & 2.7 \\
\hline Conventional tillage & 203320 & 147070 & 2.6 \\
\hline SEm \pm & 5040.86 & 5040.8 & 0.09 \\
\hline $\operatorname{LSD}(p=0.05)$ & 17444 & 17444 & 0.3 \\
\hline \multicolumn{4}{|l|}{ Nutrient management } \\
\hline $100 \% \mathrm{RDF}$ & 220727 & 164802 & 2.9 \\
\hline $120 \% \mathrm{RDF}$ & 239028 & 181223 & 3.1 \\
\hline $80 \% \mathrm{RDF}$ & 204076 & 150031 & 2.8 \\
\hline SEm \pm & 4158.4 & 4158.4 & 0.07 \\
\hline $\operatorname{LSD}(p=0.05)$ & 12466 & 12467 & 0.2 \\
\hline LSD $(p=0.05)(T \times N$ Interaction $)$ & NS & NS & NS \\
\hline
\end{tabular}

Table 2: The economics of maize-pigeon pea intercropping system affected by tillage and nutrient management practices. 


\begin{tabular}{|l|c|c|}
\hline \multirow{2}{*}{ Treatments } & \multicolumn{2}{|c|}{ Bulk density $\left(\mathrm{g} \mathrm{cm}^{-3}\right)$} \\
\cline { 2 - 3 } & Before sowing & After harvesting \\
\hline Tillage practices & 1.28 & 1.27 \\
\hline Zero Tillage & 1.27 & 1.25 \\
\hline Permanent Bed & 1.32 & 1.31 \\
\hline Fresh Bed & 1.35 & 1.34 \\
\hline Conventional tillage & 0.01 & 0.013 \\
\hline SEm \pm & 0.03 & 0.04 \\
\hline LSD (p=0.05) & & \\
\hline Nutrient management & 1.30 & 1.29 \\
\hline $100 \%$ RDF & 1.31 & 1.29 \\
\hline $120 \%$ RDF & 1.29 & 1.28 \\
\hline $80 \% R D F$ & 0.008 & 0.01 \\
\hline SEm \pm & NS & NS \\
\hline LSD (p = 0.05) & NS & NS \\
\hline LSD (p = 0.05) (T $\times N$ & & \\
Interaction) & & \\
\hline
\end{tabular}

Table 3: Physical property of pre and post-harvest of soil affected by tillage and nutrient management practices.

Nutrient management practices were not affected soil physical properties. The minimum values of bulk density were obtained in $80 \% \mathrm{RDF}\left(1.29 \mathrm{~g} \mathrm{~cm}^{-3}\right)$ and maximum was recorded in $120 \% \mathrm{RDF}$ $\left(1.31 \mathrm{~g} \mathrm{~cm}^{-3}\right)$.

Post-harvest soil.

In tillage practices, bulk density was significantly observed lower in PB (1.25 $\left.\mathrm{g} \mathrm{cm}^{-3}\right)$ whereas maximum bulk density was obtained in CT $\left(1.34 \mathrm{~g} \mathrm{~cm}^{-3}\right)$. Across the nutrient management treatments, the lower bulk density was recorded in 80\% RDF $(1.28 \mathrm{~g}$ $\mathrm{cm}^{-3}$ ) and maximum was recorded with $100 \%$ or $120 \%$ RDF (1.29 $\left.\mathrm{g} \mathrm{cm}^{-3}\right)$.

Initial soil chemical properties viz., organic carbon (OC), available phosphorous $(\mathrm{P})$ and potassium $(\mathrm{K})$ were affected by tillage practices (Table 4 and 5). Whereas nutrient management had no significant influence on soil chemical properties. In tillage practices, organic carbon was significantly superior under ZT $(0.60$ $\%$ ) and statistically at par with PB (0.59\%) as compared to FB $(0.53 \%)$ and CT $(0.48 \%)$. The available phosphorous in soil was significantly superior in ZT (32.0 $\left.\mathrm{kg} \mathrm{ha}^{-1}\right)$ which was at par with PB (32.1 $\mathrm{kg} \mathrm{ha}^{-1}$ ) as related to FB (29.2 $\left.\mathrm{kg} \mathrm{ha}^{-1}\right)$ and CT (28.5 kg ha${ }^{1}$ ). Available potassium was maximum in ZT (127.5 $\mathrm{kg} \mathrm{ha}^{-1}$ ) which

was statistically at par with PB (126.3 $\left.\mathrm{kg} \mathrm{ha}^{-1}\right)$ as compared to FB (122.7 $\mathrm{kg} \mathrm{ha}^{-1}$ ) and CT (122.0 $\mathrm{kg} \mathrm{ha}^{-1}$ ). Although available nitrogen in soil showed non-significant but higher nitrogen was recorded in ZT (227.5 $\mathrm{kg} \mathrm{ha}^{-1}$ ) followed by PB (226.2 $\left.\mathrm{kg} \mathrm{ha}^{-1}\right)$ and CT (216.9 kg ha $\left.^{-1}\right)$.

Among the nutrient management practices, the soil chemical properties were not significantly affected. The maximum organic carbon was observed in $120 \%$ RDF (0.56\%) and minimum values were obtained with $80 \%$ RDF treatment (0.54\%). Similarly, the available nitrogen was maximum in $120 \% \mathrm{RDF}\left(223.1 \mathrm{~kg} \mathrm{ha}^{-1}\right)$ followed by $100 \%$ RDF (222.5 $\mathrm{kg} \mathrm{ha}^{-1}$ ) and 80\% RDF (221.1 $\mathrm{kg} \mathrm{ha}^{-1}$ ). Available phosphorous was maximum recorded with $120 \%$ (31.1 $\mathrm{kg} \mathrm{ha}^{-1}$ ) followed by 100\% RDF (30.9 $\mathrm{kg} \mathrm{ha}^{-1}$ ) and 80\% RDF (29.3 $\mathrm{kg} \mathrm{ha}^{-1}$ ). The available potassium was maximum in $120 \%$ (126.8 kg $\mathrm{ha}^{-1}$ ) and minimum was observed in 80\% RDF (121.9 $\left.\mathrm{kg} \mathrm{ha}^{-1}\right)$.

The final soil chemical status was significantly affected by different tillage and nutrient management treatments (Table 4). Under tillage treatments, ZT and PB (0.62\% and $0.62 \%)$ showed significantly superior organic carbon as compared to FB (0.54\%) and CT (0.0.50\%). The available $\mathrm{N}$ and $\mathrm{K}$ in soil were significantly superior with PB (270.7, and $134.5 \mathrm{~kg} \mathrm{ha}^{-1}$ ) which were significantly at par with ZT (269.0 and $133.5 \mathrm{~kg} \mathrm{ha}^{-1}$ ) as compared to FB (257.0 and $129.5 \mathrm{~kg} \mathrm{ha}^{-1}$ ) and CT (255.0 and $126.3 \mathrm{~kg} \mathrm{ha}^{-1}$ ) respectively. Similarly, phosphorous is also maximum found in ZT (33.6 kg ha-1) which was significantly at par with PB (33.5 kg ha-1) and significantly over the FB and CT (30.9 and $30.5 \mathrm{~kg} \mathrm{ha}^{-1}$ ) respectively.

Although nutrient management practices showed no significant differences in soil chemical properties. The higher organic carbon was obtained with $120 \%$ RDF $(0.58 \%)$ treatment followed by $100 \%$ RDF (0.57\%) and 80\% RDF (0.56\%) treatment. 120\% RDF (268.4, 32.7 and $\left.131.7 \mathrm{~kg} \mathrm{ha}^{-1}\right)$ showed maximum available N, P and $\mathrm{K}$ content in soil. Whereas, minimum values of available $\mathrm{N}, \mathrm{P}$ and $\mathrm{K}$ was observed in 80\% RDF (257.1, 31.1 and $129.7 \mathrm{~kg} \mathrm{ha}^{-1}$ ).

\section{Discussion}

\section{Maize equivalent yield}

The maize equivalent yield was significantly affected due to the tillage practices treatment. PB treatment performed better and at par with the ZT and over the FB and CT. PB treatment was greater than other $8.25,16.60$ and $20.61 \%$ over the ZT, FB and CT treatment. This is mainly due to PB performed better in all crop growth 
stages and yield attributing characters and also, pigeon pea gave the additional yield advantage and in addition to more economic price of grain pigeon pea. Pigeon pea being a legume, fixes the atmospheric nitrogen and improves the soil fertility. There-fore soil fertility improvement might have brought in more yield so, by registering higher maize equivalent yield. Sepat., et al. 2015 [27], Singh., et al. 2018 [30] also, found in pigeon pea-wheat system.

In nutrient management treatment significantly affected the maize equivalent yield. 120\% RDF treatment and 100\% RDF treatment increment the 17.60 and $8.42 \%$ yield over the $80 \%$ RDF treatment. This was due to all yield character found more in $120 \%$ RDF treatment over the other and also nulls effects on yield of maize by intercropping Meena., et al. 2009 [15] and Krishnaprabu, 2019 [9]. Pandey., et al. 2013 [19] also, collaborated with this result.

\section{Economics}

The CA were significantly influenced the economics of maizepigeon pea intercropping. The higher gross return (244839 ₹/ha), net returns (189239 ₹/ha) and B: C ratio (3.40) were noted in PB, while lowermost values of net returns (147070 ₹/ha) and B: C ratio (2.61) were noted in CT (Table 4). The reason behind higher net returns and B: C ratio under $\mathrm{PB}$ was lower production cost and enhanced yields which lead to 28.67 and $30.26 \%$ respectively increased in net returns and B: C ratio over CT practice. While, conservation tillage systems use reduced inputs, labour and energy providing potentially more economic benefits Ram., et al. 2011 [24]. Singh., et al. 2010 [31] found under pigeon pea-wheat cropping system, Pal and Bhatnagar, [18] also noticed similar results. Parihar., et al. 2016 [20] observed similar cost of cultivation in permanent bed (PB) under different crops of maize based system. Jat., et al. 2012 [6] noticed under minimum tillage significantly more net returns and $\mathrm{B}: \mathrm{C}$ ratio compared to normal tillage.

In nutrient management level, highest gross return (239028 ₹/ha), net returns (181223 ₹/ha) and monetary advantage index (3.13) was tended to record by $120 \%$ RDF treatment that significantly higher compared to $80 \%$ RDF treatment was due to lesser cost of cultivation and higher biological yields. Pandey., et al. 2013 [19], Kumawat., et al. 2013 [10] and Vyas., et al. 2006 [35] found the similar results.

\section{Soil physical properties}

The conservation tillage practices (viz., PB and ZT) improved bulk density that lead to increase soil health. However, BD showed significant difference among the treatment, minimum values of BD was found in PB and ZT which indicates that the textural properties requires more time for change. The lower value of $\mathrm{BD}$ was due to continues addition of organic matter as crop residue leads to increase microbial population, water holding capacity. In addition, pigeon pea-based intercropping lower bulk density of the soil might be due to addition of sufficient quantity of plant leaf and stubble and their decomposition, in conservation tillage practices there will be lesser trafficking through tractor and machineries which helps to restrict soil compaction in sub layers and leads to infiltrate more amount water in soil profile. Yang and Wander, 1999 [37] reported lower BD was observed in conservation agriculture practices (CA). Similar results were also reported by Salem., et al. 2015 [26]. Pandey., et al. 2013 [19] found decrease the BD due to pigeon pea-based intercropping.

However, nutrient management practices were not significantly manipulated bulk density by the. But nutrients have some extra effects on soil physical properties. In this context, augmented supply of nutrients increases the soil microbial population which helps to improve bulk density and soil penetration resistance and ultimately improves soil physical properties. These results were in conformity with the findings of Nandapure., et al. 2011 [17]. In contracts to these some workers also reported lower improvement of soil physical properties under 100\% RDF Sinha., et al. 2013 [33]. Salahin., et al. 2011 [25] reported 100\% RDF and same doses of N supply from cow dung did not affect the BD.

\section{Soil chemical properties}

The soil chemical properties of a fixed site were significantly influenced by CA practices. Higher organic carbon, available N, P, and $\mathrm{K}$ were observed with conservation tillage practices (ZT and PB). More amount of these nutrients in soil may be due application of surface retention of residues, leaf litter fall of pigeon pea, more favorable effect of PB and ZT on root and nodules development of pigeon pea and intact remains of roots in the rhizosphere which helps to release the nutrients in soil through decomposition. In addition to this, application of organic matter to the soil supports to slowly release of nutrients and make available throughout the growing season of the succeeding crop. Further, increased organic carbon in PB and ZT helps to from organic chelates with the nutrients and reduces the loss of applied fertilizers. But, in case of CT the applied nutrients may leach to deeper soil layers, regular tillage enhanced the rate of organic matter decomposition and harm the soil fertility as well as structural stability. The developed SOC in conservation tillage practices compared to FB and CT might be due 
to more root proliferation and leaf biomass of pigeon pea. Finally, enhanced soil organic carbon, NPK status helps to improve soil health and ultimately lead to enhanced growth and development plant Phiri., et al. 2013 [22]. Singh., et al. 2009 [29] reported that the fungi present in rhizosphere of mungbean produces a glycoprotein called glomalin which helps to entraps the nutrients present in soil. Lauren., et al. 2008 [11] and He., et al. 2011 [5] also observed increment of soil nutrients under conservation agriculture practices. The improvement of nitrogen status under CA practices was reported by Wang., et al. 2008 [36] and Singh., et al. 2014 [32]. The above findings were collaborated with Betrol., et al. 2007 [1], Malhi., et al. 2011 [13] and Du Preez., et al. 2001 [3]. Higher NPK status was also observed in conservation agriculture practices by Kahlon and Singh, 2014 [7] and Kaiser., et al. 2014 [8] described improvement in soil organic carbon with adoption of CA practices.

Under nutrient management practices, 120\% RDF and 100\% RDF treatments improved soil chemical property like organic carbon and NPK status. Increase in concentration of nutrients is due to application of sufficient amount of nutrient which helps to release nutrients in to the soil by mineralization. The higher soil organic carbon and NPK status was improved with 120\% RDF treatments Singh., et al. 2014 [32]. Chesti., et al. 2013 [2] found same result at 100\% RDF over INM. and Sepehya., et al. 2012 [28] also supported with $100 \%$ RDF similar findings.

\section{Conclusion}

The maize equivalent yield was superior under PB and ZT compared to FB and CT practices and as well as same found under nutrient management practices $120 \%$ RDF found maximum MEQ compared to $100 \%$ and $80 \%$ RDF treatment. The MEQ value affected the economics of intercropping system so that maximum economic benefit found under $\mathrm{PB}$ and ZT practices compared to CT and $120 \%$ RDF over to $100 \%$ and $80 \%$ RDF. The physico-chemical property superior under PB and ZT compared to CT practices.

\section{Acknowledgment}

I am amply delighted to express my gratitude to the Vice-Chancellor, RPCAU, Pusa. for refilling me the financial assistance in the form of fellowship during my post-graduation studies. I am very much thankful to the help and cooperation of non-teaching staffs of the Department of Agronomy for their help and support.

\section{Bibliography}

1. Betrol I., et al. "Phosphorus, potassium and organic carbon concentrations in runoff water and sediments under different soil tillage systems during soybean growth". Soil and Tillage Research 94 (2007): 142-150.

2. Chesti MH., et al. "Effect of integrated nutrient management on yield of and nutrient uptake by wheat (Triticum aestivum) and soil properties under intermediate zone of Jammu and Kashmir". Journal of the Indian Society of Soil Science 61.1 (2013): $1-6$.

3. Du Preez CC., et al. "Long-term effects of wheat residue management on some fertility indicators of a semi-arid Plinthosol". Soil and Tillage Research 63 (2001): 25-33.

4. Gangwar K S., et al. "Alternate tillage and crop residue management in wheat after rice in sandy loam soil of Indo-Gangetic plains". Soil and Tillage Research 88 (2006): 242-252.

5. He J., et al. "Soil properties and crop yields after 11 years of no tillage farming in wheat-maize cropping system in North China Plain". Soil and Tillage Research 113.1 (2011): 48-54.

6. Jat R M., et al. "Effect of conservation agriculture on productivity and economics of different cropping systems under rainfed condition in the semiarid tropics". 3rd International Agronomy congress 3 (2012): 888-890.

7. Kahlon M S and G Singh. "Effect of Tillage Practices on Soil Physico-chemical Characteristics and Wheat Straw Yield". International Journal of Agricultural Sciences 4.10 (2014): 289293.

8. Kaiser M., et al. "Impact of tillage intensity on carbon and nitrogen pools in surface and sub-surface soils of three longterm field experiments". European Journal of Soil Science 65.4 (2014): 499-509.

9. Krishnaprabu S. "Influence on Intercropped Cajanus Cajan Caused By Land Configuration, Post-Monsoon Irrigation, and P Fertilization". International Journal of Innovative Technology and Exploring Engineering (2019): 457-429.

10. Kumawat N., et al. "Effect of integrated nutrient management on the performance of sole and intercropped pigeon pea (Cajanus cajan) under rainfed conditions". Indian Journal of Agronomy 58.3 (2013): 309-315.

11. Lauren JG., et al. "Research station and on-farm experiences with permanent raised beds through the Soil Management Collaborative Research Support Program". In Permanent Beds and Rice-residue Management for Rice-wheat Systems in the Indo-Gangetic Plain. Proceedings of a Workshop Held in Ludhiana, India (2006): 124-132. 
12. MI Dawelbeit and EA Babiker. "Effect of tillage and sowing method on growth and yield of wheat". Soil and Tillage Research 42 (1997): 127-132.

13. Malhi SS., et al. "Long-term tillage, straw and $\mathrm{N}$ rate effects on quantity and quality of organic C and $\mathrm{N}$ in a Gray Luvisol soil". Nutrient Cycling in Agroecosystems 90 (2011): 1-20.

14. McKersie Bryan. "Planning for food security in a changing climate". Journal of Experimental Botany 66.12 (2015): 34353450 .

15. Meena SL., et al. "Production of cluster bean (Cyamopsis tetragonoloba) and sesame (Sesamum indicum) intercropping system under different row ratio and nutrient management in arid region". Indian Journal of Agricultural Sciences 79.11 (2009): 901-905.

16. N Ahmad., et al. "Fertilizer and their use in Pakistan, NFDC". Publication, No. 4/96, 2nd Ed, Islamabad (1996).

17. Nandapure S P., et al. "Long term effects of integrated nutrient management on soil physical properties and crop productivity in sorghum-wheat cropping sequence in a vertisol". Indian Journal of Agricultural Research 45.4 (2011): 336-340.

18. Pal MS and Bhatnagar A. "Tillage options and nutrient management in hybrid maize (Zea mays L.)". In: Abstract of 12th Asian maize conference and export consultation on maize for food, feed, nutrition and environmental security. 30th 0ct-1st Nov, Bankok, Thailand 102.

19. Pandey IB., et al. "Integrated nutrient management for sustaining the productivity of pigeon pea (Cajanus cajan) based intercropping systems under rainfed condition". Indian Journal of Agronomy 58.2 (2013): 192-197.

20. Parihar CM., et al. "Energy scenario and water and productivity of maize based cropping system under conservation agriculture practices in south Asia". In: Abstracts of 5th world congress on conservation agriculture, incorporating the 3rd farming system design conference held at Brisbane, Australia from 26th to 29th (2011): 144-145.

21. Paul J., et al. "Bioresource nutrient recycling and its relationship with biofertility indicators of soil health and nutrient dynamics in rice-wheat cropping system". Communications in Soil Science and Plant Analysis 45.7 (2014): 912-924.

22. Phiri AT., et al. "Assessment of nutrient and biomass yield of medium and long duration pigeon pea in a pigeon peagroundnut intercropping system in Malawi”. Journal of Sustainable Society 2.1 (2013): 36-48.
23. R GD Steel., et al. "Principles and procedures of statistics, A Biometrical Approach". 3rd Ed. McGraw Hill, Inc. Book Co. N.Y. (U.S.A.) (1997).

24. Ram H., et al. "Agronomic and economic evaluation of permanent raised beds, no tillage and straw mulching for an irrigated maize-wheat system in NorthWest India". Experimental Agriculture 48.1 (2011): 21-38.

25. Salahin N., et al. "Effect of tillage and integrated nutrient management on soil physical properties and yield under tomatomungbean-t. aman cropping pattern". International Journal of Sustainable Crop Production 6.1 (2011): 58-62.

26. Salem H M., et al. "Short-term effects of four tillage practices on soil physical properties, soil water potential, and maize yield". Geoderma 237 (2015): 60-70.

27. Sepat S., et al. "Effect of conservation agriculture practices on productivity and sustainability of pigeon pea (Cajanus cajan)wheat (Triticum aestivum) cropping system in Indo-Gangetic plains of India”. Indian Journal of Agricultural Sciences 85.2 (2015): 212.

28. Sepehya S., et al. "Effect of integrated nutrient management on rice-wheat yield and soil properties in a north western Himalayan region". Indian Journal of Soil Conservation 40.2 (2012): $135-140$.

29. Singh G., et al. "Effect of resource-conserving techniques on soil microbiological parameters under long-term maize (Zea mays) - wheat (Triticum aestivum) crop rotation". Indian Journal of Agricultural Sciences 79.2 (2009): 94-100.

30. Singh U., et al. "Up-scaling nutrient, energy and system productivity of pigeon pea-wheat cropping system in Indo-Gangetic plains of India”. Journal of Environmental Biology 39.5 (2018): 647-658.

31. Singh V K., et al. "Permanent raised bed planting of the pigeon pea-wheat system on a Typic Ustochrept: Effects on soil fertility, yield, and water and nutrient use efficiencies". Field Crops Research 116 (2010): 127-139.

32. Singh VK., et al. "Optimizing nutrient management strategies for rice-wheat system in the Indo-Gangetic Plains of India and adjacent region for higher productivity, nutrient use efficiency and profits". Field Crops Research 164 (2014): 30-44.

33. Sinha K K., et al. "Yield and economics as influenced by winter maize (Zea mays) based intercropping system in North Bihar". Indian Journal of Agronomy 44.1 (1999): 30-35. 
34. Tomar SS and Tiwari SS. "Production potential and economics of different crop sequences". Indian Journal of Agronomy 35 (1990): 30-35.

35. Vyas MDS. "Integrated nutrient management in pigeon pea+soybean intercropping system under rainfed conditions". Mysore Journal of Agricultural Sciences 44.4 (2010): 781-785.

36. Wang Q., et al. "Soil chemical properties and microbial biomass after 16 years of no-tillage farming on the Loess Plateau, China". Soil and Tillage Research 144 (2008): 502-508.

37. Yang XM and Wander MM. "Tillage effects on soil organic carbon distribution and storage in a silt loam soil in Illinois". Soil and Tillage Research 52 (1999): 1-9.

\section{Assets from publication with us}

- Prompt Acknowledgement after receiving the article

- Thorough Double blinded peer review

- Rapid Publication

- Issue of Publication Certificate

- High visibility of your Published work

Website: www.actascientific.com/

Submit Article: www.actascientific.com/submission.php

Email us: editor@actascientific.com

Contact us: +919182824667

Citation: Pradeep Kumar., et al. "Effect of Tillage and Nutrient Management on Economics and Soil Status by Maize + Pigeon Pea Intercropping System". Acta Scientific Agriculture 4.12 (2020): 40-47. 